\title{
Interaction model of steel ladle of continuous caster in steel works
}

\author{
Bang Fu HUANG ${ }^{1, a}$, Zhi Wei MA ${ }^{1}$, Nai Yuan TIAN $^{2}$, Zhe SHI ${ }^{1}$, Xiao Lei ZHOU $^{1}$, Jun CAI ${ }^{3}$ \\ ${ }^{1}$ Faculty of Metallurgical and Energy Engineering, Kunming University of Science and Technology, Kunming 650093, China. \\ ${ }^{2}$ School of Metallurgical and Ecological Engineering, University of Science and Technology Beijing, Beijing 100083, China \\ ${ }^{3}$ Sinosteel Jinxin Consulting Company Co Ltd, Beijing 100080, China.
}

\begin{abstract}
For further research on the precondition and interoperability model of interaction ladles among continuous caster, this article takes steel ladle of Y steel works as the object of research. On the basis of turnover number calculation model of single cast steel ladle, the relationship between cast number and the turnover number and turnover times and last turnover number are further analyzed. The simulation of steel ladle turnover rules was taken on the 2 continuous casters with Gantt chart. After that, the relationships between turnover number and last turnover number and non-turnover number are researched deeply. Combining with the Gantt chart, the expressions of start casting time and empty ladle ending time and heavy ladle starting time were put forward. The precondition of steel ladle interaction is obtained, which means the exchange ladle should not undertaking transport task in first stop continuous caster, and the empty ladle end time of exchange ladle of first stop continuous caster should early than the heavy ladle start time of last stop continuous caster. After applying the model to practice, 3 steel ladles of No. 2 continuous caster can be reduced. This research results is supplying theoretical basis for steel ladle controlling and production organization optimization, and enriches the theory and method of metallurgical process integration.
\end{abstract}

\section{Forward}

As the interface technique between blast furnace and basic oxygen furnace continuous improvement, steel ladle is the vessel of liquid steel transporting between basic oxygen furnace(BOF) and continuous caster(CC) interface, and is the main tool of control steel temperature and production rhythm ${ }^{[1-2]}$. Besides, steel ladle is the buffer $^{[3]}$ of production rhythm. Its turnover number and operation efficiency and buffer capability are the key factors of control production and matching procedures. In a certain period of time, the less turnover number of steel ladle represents the higher turnover ratio and hot tapping ratio. At the same time, reducing turnover number has practical significance for reducing tapping temperature and keeping stabilization casting in $\mathrm{CC}^{[4]}$. However, how to reduce turnover number of steel ladle? Reducing number is the hot and difficult of production scheduling in steel works. Studies have shown that steel ladle interaction is an effective way to reduce the turnover number. What is the precondition and model of steel ladle interaction? Nowadays, the existing research results of steel ladle interaction is rare in reference.

Among the existing research results, the number of steel ladle is focused on calculation method, such as production method, time calculation method and turnover period matching method ${ }^{[5]}$. The result of the study is only applicable to the ideal state of single equipment and has more limited conditions. The turnover rule of steel ladle is simulated by Gantt chart under the condition of singlecast and multi-casts ${ }^{[6]}$. Furthermore, the calculation

\footnotetext{
a kmusthbf@163.com
} 
model under different overlap heats is put forward, this method only consider overlap heat number, without the other factors on the influence of the ladle interaction among continuous casters. The author has done the ladle number calculation model of 2 and 3 continuous casters. The model is under the different overlapping time of casts $^{[7-9]}$. Moreover, the revolving model under the condition of saving ladle of steel also carried on through research $^{[10-11]}$. The ladle number calculation model was also put forward based on smelting cycle of basic oxygen furnace single heat bigger than or less than the casting time of continuous caster single heat. From the existing research, we can see that the precondition and influence factor of steel ladle interaction are not discussed. Therefore, using existing theory or method of ladle interaction, the application effect is apparently not good.

For further research on the precondition and interoperability model of steel ladles interaction among continuous casters, this article takes steel ladle of Y steel works as the object of research. The operation process and time is analyzed. The relationship among various parameters of single cast in CC is deeply researched. The relational expression of turnover times and turnover number and last turnover number is proposed. The turnover rules of steel ladle were simulated by using Gantt chart. Based on time expression of empty ladle finish and heavy ladle start, the precondition and interoperability model of steel ladles interaction is proposed.

\section{Operation process analysis of steel ladle}

In order to research the model of steel ladle interaction between CCs, the operation process and time should be controlled firstly ${ }^{[12]}$. There has 3 basic oxygen furnaces(BOF) of 100t, 2 ladle furnace(LF), $1 \mathrm{RH}$ and 2 continuous casters $(\mathrm{CC})$ of slab in Y steel works. Besides, $\mathrm{Y}$ steel works has 3 online baking positions(ONBP), 2 offline baking positions(OFBP), 1 hot repair position(HRP) and 2 de-slagging positions(DP). Through analyzing the operation process of steel ladle, the operation phase includes heavy operation and CC casting and empty operation. Operation phase of heavy ladle has 2 operation routes, which includes BOF-LF-CC and BOF-LF-RH-CC. The liquid steel of BOF-LF-CC route can supply to No.1 CC and No.2 CC. The liquid steel of BOF-LF-RH-CC route is just supply to No.2 CC. Operation phase of empty ladle has 2 operation routes, which includes DP-HRP-ONBP-BOF and DP-HRPOFBP-BOF.

All the above operation time can be measured and statistics and inductive. As shown in Table 1.

Table 1. Operation time of steel ladle.

\begin{tabular}{|c|c|c|c|}
\hline Time & Time term & $\begin{array}{c}\text { Average } \\
\text { value } \\
\text { /min }\end{array}$ & Remark \\
\hline \multirow{3}{*}{$\begin{array}{l}\text { Operation } \\
\text { time of } \\
\text { heavy } \\
\text { steel ladle }\end{array}$} & \multirow{3}{*}{$\begin{array}{c}\text { Tapping } \\
\text { time+Refining } \\
\text { time+Transportation } \\
\text { time+Waiting time }\end{array}$} & 78 & $\begin{array}{l}\text { “BOF-LF- } \\
\text { CC"refining } \\
\text { route of No.1 } \\
\text { CC's liquid } \\
\text { steel }\end{array}$ \\
\hline & & 74 & $\begin{array}{l}\text { "BOF-LF- } \\
\text { CC"refining } \\
\text { route of No.2 } \\
\text { CC's liquid } \\
\text { steel } \\
\end{array}$ \\
\hline & & 115 & $\begin{array}{l}\text { "BOF-LF-RH- } \\
\text { CC"refining } \\
\text { route of No.1 } \\
\text { CC's liquid } \\
\text { steel }\end{array}$ \\
\hline \multirow{2}{*}{$\begin{array}{c}\text { Casting } \\
\text { time of } \\
\text { single heat }\end{array}$} & $\begin{array}{l}\text { Single heat casting } \\
\text { time of No.1 CC }\end{array}$ & 32 & $\begin{array}{l}\text { Steel ladle of } \\
\text { No.1 CC }\end{array}$ \\
\hline & $\begin{array}{l}\text { Single heat casting } \\
\text { time of No.2 CC }\end{array}$ & 27 & $\begin{array}{c}\text { Steel ladle of } \\
\text { No.2 CC } \\
\end{array}$ \\
\hline $\begin{array}{l}\text { Operation } \\
\text { time of } \\
\text { empty } \\
\text { steel ladle }\end{array}$ & $\begin{array}{c}\text { Deslagging } \\
\text { time+Repairing } \\
\text { time+Baking } \\
\text { time+Transportation } \\
\text { time+ Waiting time }\end{array}$ & 63 & $\begin{array}{l}\text { "DP-HRP- } \\
\text { ONBP- } \\
\text { BOF"operation } \\
\text { route of No.1 } \\
\text { CC's steel } \\
\text { ladle }\end{array}$ \\
\hline
\end{tabular}

Based on Table 1, turnover cycle of steel ladle can be calculated by follows equation:

$$
T_{\text {cycle }}^{\text {ladle }}=T_{\text {heavy }}^{\text {ladle }}+T_{\text {cast }}^{C C}+T_{\text {empty }}^{\text {ladle }}
$$

Where $T_{\text {cycle }}^{\text {ladle }}$ represents turnover cycle of steel ladle, min. $T_{\text {heavy }}^{\text {ladle }}$ represents operation time of heavy ladle, min. $T_{\text {cast }}^{C C}$ represents single heat casting time of $\mathrm{CC}$, min. $T_{\text {empty }}^{\text {ladle }}$ represents operation time of empty ladle, min. 
According to table 1, by using Eq. (1), the steel ladle turnover cycle of No.1 CC can be calculated, which equals $173 \mathrm{~min}$. The steel ladle turnover cycle of No.2 $\mathrm{CC}$ equals 164 min under the operation route of BOF-LFCC. The steel ladle turnover cycle of No.2 CC equals 205 min under the operation route of BOF-LF-RH-CC.

\section{Number calculation model of single cast steel ladle}

In order to research the precondition of steel ladle interaction, the ladle turnover number of single cast need to be confirmed. The existing research has mature research results of number calculation model ${ }^{[6-8]}$. As shown in formula (2) and (3).

$$
\begin{gathered}
n_{\text {ladle }}^{C C}=\left\lceil\frac{T_{\text {cycle }}^{\text {ladle }}}{T_{\text {cast }}^{C C}}\right\rceil \\
n_{\text {ladle }}^{C C}=\left[1+\frac{T_{\text {heavy }}^{\text {ladle }}+T_{\text {empty }}^{\text {ladle }}}{T_{\text {cast }}^{C C}}\right\rceil
\end{gathered}
$$

Where $n_{\text {ladle }}^{C C}$ represents steel ladle turnover number of single cast; \lceil\rceil represents the symbol of round up to an integer.

According to formula (2) and (3), the number calculation model of single cast turnover ladle means that $\mathrm{CC}$ can cast number of liquid steel during turnover cycle. According to single heat casting time equals $32 \mathrm{~min}$ and turnover cycle equals $173 \mathrm{~min}$, by applying Eq. (2), the No.1 CC needs 5.4 steel ladles for single casting, the number is 6 for round up to an integer. According to single heat casting time equals $27 \mathrm{~min}$ and turnover cycle equals 164 min, by applying Eq. (2), the No.2 CC needs 6.1 steel ladles for single casting under the operation route of BOF-LF-CC, the number is 7 for round up to an integer. This works choose the heavy ladle of "BOF-LF$\mathrm{CC}$ " route as the object of research. At the same time, empty ladle choose "DP-HRP-ONBP-BOF" route.

\section{Model of steel ladle interaction}

The steel ladle will be exchange to other continuous caster for new transportation task once it has finished turnover, which means the interoperability among different continuous casters are realized. In some cases, the turnover number of steel ladle in steel works can reduce under some condition.

The casting heats of CC's single cast can be expressed by turnover time and turnover number and last turnover number, which is shown in formula (4).

$$
N_{\text {heat }}^{C C}=i^{C C} \times n_{\text {ladle }}^{C C}+h_{\text {ladle }}^{C C}
$$

In the equation, $N_{\text {heat }}^{C C}$ represents casting heats of CC's single cast, $i^{C C}$ represents complete turnover times of steel ladle, time. $h_{\text {ladle }}^{C C}$ represents the number of steel ladle which needs turnover again after $n_{\text {ladle }}^{C C}$ turnovers $i^{C C}$ times, $0 \leq h_{\text {ladle }}^{C C}<n_{\text {ladle }}^{C C}$.

By the research, the single cast of No.1 CC needs 21 heats, it can be shown in the expression of $21=3 \times 6+3$ by using Eq.(4), the 21 heats of single cast needs 6 steel ladles turnover 3 times and the first 3 steel ladles turnover one more time again. Meanwhile, the single cast of No.2 $\mathrm{CC}$ needs 25 heats, the expression of $25=3 \times 7+4$ can be obtained, the 25 heats of single cast needs 7 steel ladles turnover 3 times and the first 4 steel ladles turnover one more time again.

Gantt chart is an effective tool for planning production scheduling, and the relationship between production plan and each procedure can be vivid shown ${ }^{[13]}$. The Gantt chart of operation rules of 2 CC's steel ladle are simulated, the operation process of steel ladle in various segment of time process can be shown. Based on the results above, the precondition and model of steel ladle interaction can be in-depth studied. Gantt chart is a set of lines chart, which horizontal axis represents time and vertical axis represents activities and lines represents project performance ${ }^{[14-16]}$.

The Gantt chart sets No.1 CC first start and stopping casting, and No.2 CC last start casting. The overlapping time between $2 \mathrm{CCs}$ is $46 \mathrm{~min}$. According to the calculation results of Eq.(4), the Gantt chart is just simulated steel ladle turnover rules of No.1 CC's last 9 heats and No.2 CC's first 7 heats, the feasibility of steel 
ladle interaction between CCs can be analyzed. As shown in Fig.1.

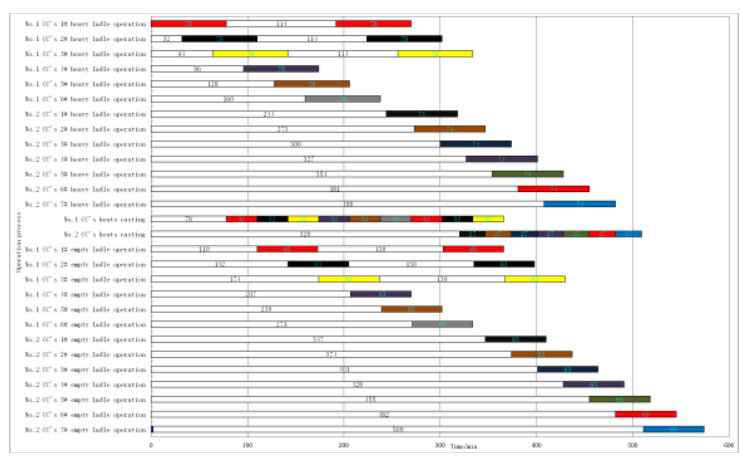

Figure 1. Gantt chart of 2 CCs' steel ladle.

As show in Fig.1, a color of line section represents the same steel ladle of CC. The last 9 steel ladles of No.1 CC need the red ladle and black ladle and yellow ladle turnover one more time again after all of ladles turnover 3 times. However, the violet ladle and brown ladle and gray ladle are finished transport task after turnover 3 times. This simulation results is consistent to the calculation results by Eq.(4).

For No.2 CC last casting, it is need to observe the 7 steel ladles, whether some ladle can exchange to No.1 for replacing $4 \# / 5 \# / 6 \#$ steel ladle. After that, the turnover number of No.2 CC's steel ladles can reduce.

The relationship between last need turnover number and non turnover ladle is expressed by Eq.(5) and Eq.(6) and Eq.(7).

$$
\begin{gathered}
g=n_{\text {ladle }}^{C C}-h \\
g=n_{\text {ladle }}^{C C}-\left(N_{\text {heat }}^{C C}-i \times n_{\text {ladle }}^{C C}\right) \\
g=n_{\text {ladle }}^{C C} \times(1+i)-N_{\text {heat }}^{C C}
\end{gathered}
$$

Where $g$ represents the last non turnover ladle of CC's cast.

According to Eq.(5) and Eq.(6) and Eq.(7), the serial number of last non turnover and exchange ladle can express by Eq.(8).

$$
k_{r}^{C C}=N_{\text {heat }}^{C C}-n_{\text {ladle }}^{C C}+r
$$

Where $k_{r}^{C C}$ represents serial number of non turnover ladle of CC's cast, $r$ represents the serial number of exchang ladle in non turnover ladle, $1 \leq r \leq g$.
Through analyzing single cast's steel ladle, the start casting time can express by Eq.(9).

$$
T_{k s}^{C C}=t_{1 s}^{C C}+(k-1) \times T_{c a s t}^{C C}
$$

Where $T_{k s}^{C C}$ represents the start casting time of No. $k$ steel ladle, min. $t_{1 s}^{C C}$ represents the start casting time of No.1 steel ladle, min. $k$ represents the order number of continuous casting heats.

Based on Eq.(1) and Eq.(9), the end time of No. $k$ empty steel ladle can be expressed as shown in Eq.(10).

$$
T_{\text {ke-e }}^{C C}=t_{1 s}^{C C}+k \times T_{\text {cast }}^{C C}+T_{\text {empty }}^{\text {ladle }}
$$

Where $T_{k e-e}^{C C}$ represents the end time of No. $k$ empty steel ladle, $\min$ 。

Based on Eq.(8) and Eq.(10), the end time of No.1 CC's empty steel ladle can be expressed as shown in Eq.(11) and Eq.(12).

$$
\begin{array}{r}
T_{\text {ke-e }}^{C C 1}=t_{1 s}^{C C 1}+k_{r}^{C C 1} \times T_{\text {cast }}^{C C 1}+T_{\text {empty }}^{C C 1 \text {-ladle }} \\
T_{\text {ke-e }}^{C C 1}=t_{1 s}^{C C 1}+\left(N_{\text {heat }}^{C C 1}-n_{\text {ladle }}^{C C 1}+r\right) \times T_{\text {cast }}^{C C 1}+T_{\text {empty }}^{C C 1 \text {-ladle }}
\end{array}
$$

With similar to Eq.(10), the start time of No. $k$ heavy ladle can be expressed by Eq.(13).

$$
T_{k h-s}^{C C}=t_{1 s}^{C C}+(k-1) \times T_{\text {cast }}^{C C}-T_{\text {heavy }}^{\text {ladle }}
$$

Where $T_{k h-s}^{C C}$ represents the start time of No. $k$ heavy steel ladle, min。

In term of No. 2 CC, the start time of No. $k$ heavy ladle can be expressed by Eq.(14).

$T_{k h-s}^{C C 2}=t_{1 s}^{C C 2}+\left(k^{C C 2}-1\right) \times T_{\text {cast }}^{C C 2}-T_{\text {heavy }}^{C C 2 \text {-ladle }}$

Though analyzing Fig.1 and Eq.(11) and Eq.(14), steel ladle interaction from No.1 CC to No.2 CC need to satisfy the precondition as shown below.

(1) The exchange ladle should not undertaking transport task of liquid steel in No.1 CC.

(2) The empty ladle end time of No.1 CC's exchange ladle should early than the heavy ladle start time of No.2 CC's steel ladle.

Based on above condition, the exchange time can be expressed by Eq.(15). 


$$
T_{k e-e}^{C C 1}-T_{k h-s}^{C C 2} \leq 0
$$

Taking Eq.(11) and Eq.(14) into Eq.(15), it can be gained Eq.(16).

$\left[t_{1 s}^{C C 1}+k_{r}^{C C 1} \times T_{\text {cast }}^{C C 1}+T_{\text {empty }}^{C C 1 \text { ladle }}\right]-\left[t_{1 s}^{C C 2}+\left(k^{C C 2}-1\right) \times T_{\text {cast }}^{C C 2}-T_{\text {heavy }}^{C C 2 \text {-ladle }}\right] \leq 0$ (16)

By applying Eq.(15) and Eq.(16), the feasibility of steel ladle interaction between No.1 CC and No.2 CC can be analyzed. This interaction condition can supply scientific basis for reducing turnover number of steel ladle.

\section{Model applying}

The interaction feasibility of steel ladle under the condition of Fig.1 is analyzed by applying interaction model. Based on analyzing result of Eq.(4), the $4 \#$ and 5\# and $6 \#$ ladle of No.1 CC is finished transport task after turnover 3 times. The $t_{1 s}^{C C 1}$ sets $0 \mathrm{~min}$. The end time of $4 \#$ and 5\# and 6\# empty ladle is calculated from Eq.(5) to Eq.(12). The result is shown in Table 2.

Table 2. Empty ladle's ending time of $4 \#$ and 5\# and 6\# steel ladle of No.1 CC.

\begin{tabular}{|c|c|c|c|c|c|c|c|c|c|}
\hline $\begin{array}{l}N_{\text {heat }}^{C C 1} \\
\text { /heat }\end{array}$ & $n_{l a d}^{C D}$ & $h$ & $\mathrm{~g}$ & $\begin{array}{l}T_{\text {cast }}^{C C 1} \\
/ \mathrm{min}\end{array}$ & $\begin{array}{c}T_{\text {empty }}^{C C 1-l a d} \\
/ \mathrm{min}\end{array}$ & $\begin{array}{l}\mathrm{N} \\
\mathrm{o}\end{array}$ & $r$ & $\begin{array}{l}k_{r}^{C C} \\
1 \text { 个 }\end{array}$ & $\begin{array}{l}T_{k e-e}^{C C 1} \\
/ \mathrm{min}\end{array}$ \\
\hline \multirow{3}{*}{21} & \multirow{3}{*}{6} & \multirow{3}{*}{3} & \multirow{3}{*}{3} & \multirow{3}{*}{32} & \multirow{3}{*}{63} & $\begin{array}{l}4 \\
\#\end{array}$ & 1 & 16 & 575 \\
\hline & & & & & & $\begin{array}{l}5 \\
\#\end{array}$ & 2 & 17 & 607 \\
\hline & & & & & & $\begin{array}{l}6 \\
\#\end{array}$ & 3 & 18 & 639 \\
\hline
\end{tabular}

The overlapping time between 2 CCs equals $46 \mathrm{~min}$.

the start casting time of No.2 CC's first heat is calculated and equals $626 \mathrm{~min}$ by using Eq.(9). The start time of No.2 CC's 7 heavy ladles is calculated by using Eq.(14). As shown in Table 3.

Table 3. Heavy ladle's start time of No.2 CC's steel ladle.

\begin{tabular}{|c|c|c|c|c|c|}
\hline $\begin{array}{l}\mathrm{N} \\
\mathrm{o} .\end{array}$ & $\begin{array}{c}t_{1 s}^{C C 2} / \\
\min \end{array}$ & $\begin{array}{c}k^{C C 2} / \mathrm{h} \\
\text { eat }\end{array}$ & $\begin{array}{c}T_{\text {cast }}^{C C 2} / \\
\min \end{array}$ & $\begin{array}{c}T_{\text {heavy }}^{C C 2 \text { ladle }} \\
\quad / \mathrm{min}\end{array}$ & $\begin{array}{c}T_{k h-\mathrm{s}}^{C C 2} / \\
\min \end{array}$ \\
\hline $1 \#$ & \multirow{7}{*}{626} & 1 & \multirow{7}{*}{27} & \multirow{7}{*}{63} & 563 \\
\hline $2 \#$ & & 2 & & & 590 \\
\hline $3 \#$ & & 3 & & & 617 \\
\hline $4 \#$ & & 4 & & & 644 \\
\hline $5 \#$ & & 5 & & & 671 \\
\hline $6 \#$ & & 6 & & & 698 \\
\hline $7 \#$ & & 7 & & & 725 \\
\hline
\end{tabular}

By using judging condition of steel ladle interaction, $T_{k e-e}^{C C 1}$ contrast to $T_{k h \text {-s }}^{C C 2}$, the comparison result is shown in Table 4.

Table 4. Steel ladle interaction between No.1 CC and No.2 CC.

\begin{tabular}{|c|c|c|c|}
\hline $\begin{array}{l}\text { No.1 } \\
\text { CC's } \\
\text { steel } \\
\text { ladle } \\
\end{array}$ & $\begin{array}{l}\text { Judging } \\
\text { condition }\end{array}$ & $\begin{array}{c}\text { Be replaced } \\
\text { ladle of No.2 } \\
\text { CC }\end{array}$ & $\begin{array}{c}\text { Optimal replaced } \\
\text { plan of No. } 2 \text { CC's } \\
\text { steel ladle }\end{array}$ \\
\hline 4\# & \multirow{3}{*}{$\begin{array}{c}T_{k e-e}^{C C 1}- \\
T_{k h-s}^{C C 2} \leq 0\end{array}$} & $\begin{array}{l}2 \#, 3 \# 、 \\
4 \#, 5 \# 、 \\
6 \# 、 7 \#\end{array}$ & $2 \#$ \\
\hline $5 \#$ & & $\begin{array}{c}\text { 3\#、4\#、 } \\
\text { 5\#、6\#、7\# }\end{array}$ & $3 \#$ \\
\hline $6 \#$ & & $\begin{array}{l}\text { 4\#、5\#、 } \\
6 \# 、 7 \#\end{array}$ & 4\# \\
\hline
\end{tabular}

In Table 4, the optimal replaced plan means the minimum temperature drop loss and quickly start next turnover. No.2 CC has 3 steel ladles that can be replaced by No.1 CC's ladle under the condition of optimal replaced plan, which means No.2 CC less investment 3 steel ladles.

From what has been discussed above, the analyzing interaction feasibility of steel ladle between CCs should control the turnover rules and cycle and number firstly, and analyze the relationship between empty ladle end time and heavy ladle start time, and propose the optimal replaced plan. Studies have shown that the cast plan and casting time of rational control and matching can raise the non-turnover number and probability of steel ladle interaction.

\section{Figures and tables}

(1) The turnover cycle and number of steel ladle is described under the condition of single CC. The relationship between turnover number and heavy ladle operation time and empty ladle operation time and casting time is analyzed.

(2) The operation rules of 2 CCs steel ladle is simulated under the condition of 46 min overlapping time by using Gantt chart. The relationship between heat number and turnover number and turnover times and non turnover number is analyzed. Based on start casting time and casting time of No.1 heat, the expression of empty ladle end time and heavy ladle start time is proposed by analyzing empty ladle and heavy ladle operation time.

(3) The precondition of steel ladle interaction is obtained, which means the exchange ladle has no need of 
undertaking transport task in first stop $\mathrm{CC}$, and the empty ladle end time of exchange ladle of first stop CC should early than the heavy ladle start time of last stop CC.

(4) The model is applied to practice. There has 3 steel ladles of No.2 CC that can be replaced by $4 \#$ and 5\# and 6\# ladle of No.1 CC. the optimal replaced plan is $2 \#$ and 3\# and 4\# ladle of No.1 CC replaced by No.2 CC's steel ladle. Besides, this research results is supplying theoretical basis for steel ladle controlling and production organization optimization. At the same time, it enriches the theory and method of metallurgical process integration.

\section{References}

1.Y Ruiyu. Metallurgical Process Engineering. the 2st Edition (2009)

2.H Bangfu, S Zhe, D Yuehua. Journal of Kunming University of Science and Technology(Natural Science Edition), 38(3),(2013)

3. Y Ruiyu. Theory and Method of Metallurgical Process Integration. the 1st Edition (2013)

4. Y Ruiyu. Acta Metall Sin, (1993).

5. L Qing, Z Ping, W Xiaodong. Journal of University of Science and Technology Beijing, , 27(2),(2005)

6. C Jun, H Dongfeng, $\mathrm{W}$ Hongbing. Journal of Chongqing University,,36(11),(2013)

7. H Bangfu,W Jianjun,Z Daofei. Journal of Iron and Steel Research ,26(5),(2014)

8. H Bangfu, S Zhe, Z Hongbo. Journal of Central South University (Science and Technology), 45(7),(2014)

9. H Bangfu, Z Xiaolei, Z Guifang. Applied Mechanics and Materials, (2014)

10. H Bangfu, F Bo, W Jianjun. Iron and Steel, 49(4),(2014)

11. H Bangfu, Z Xiaolei, Z Guifang. Advanced Materials Research, 1015, (2014)

12. H Bangfu. University of Science and Technology Beijing,(2011)

13. C Jun. University of Science and Technology Beijing,(2015)

14. H Dongfeng, Y Gang, X Anjun. Journal of University of Science and Technology Beijing, 32(12),(2010)

15. W Jinming, Z Kun,L Shenghui. Shandong Metellury, 31(5),(2009)

16. Maylor H. Beyond the Gantt chart Project management moving on EurManage. 19(1),(2001)

\section{Acknowledgements}

This work is supported by China Postdoctoral Science Foundation No.57 (No.2015M572647XB) and the Science Research Program of Yunnan Province Education Department(No.2014Y069). 